\title{
BUILDING CULTURAL LITERACY THROUGH THE PATTINGALLOANG BOAT LIBRARY
}

\author{
Muhammad Qasim*, Ahmad M. Sewang*, Muhammad Yaumi*, \& \\ Arifuddin Siraj*
}

\author{
*Universitas Islam Negeri Alauddin Makassar \\ Email:qasim107@gmail.com,ahmad.sewang@uin-alauddin.ac.id,muhammad.yaumi@uin- \\ alauddin.ac.id, \& arifuddin.siraj@uin-alauddin.ac.id
}

(Submitted: 21-10-2019, Revised: 30-11-2019, Accepted: 30-11-2019)

DOI: $10.24252 /$ kah.v7i2a3

\begin{abstract}
ABSTRAK: Membangun Indonesia menjadi sebuah negara maju bukanlah pekerjaan yang mudah dan tidak dapat diwujudkan dalam waktu yang singkat. Literasi ialah kemampuan untuk memahami materi bacaan dan menulis. Pembangunan budaya literasi ialah syarat utama yang dapat digunakan untuk membangun sumber daya manusia yang unggul. Tulisan ini bertujuan untuk menganalisis tantangan dan peluang perahu pustaka Pattingalloang dalam membangun literasi budaya. Kajian ini diharapkan dapat memberikan kontribusi nyata kepada pemerintah dan masyarakat dalam mengharmonisasikan dan mengakselerasi pembangunan literasi budaya. Penelitian ini ialah penelitian deskriptif kualitatif. Data diperolah dari fakta empiris di lapangan dan melalui dokumen yang relevan. Hasil penelitian menunjukkan bahwa pertama masyarakat Indonesia memiliki minat baca yang besar namun media pendukung masih sangat terbatas. Kedua, perahu pustaka Pattingalloang hadir karena dua alasan yaitu pertama karena budaya literasi dan literasi budaya, dan kedua karena kontribusi masyarakat dalam membangun literasi.
\end{abstract}

Kata kunci: Perahu pustaka; budaya literasi; literasi budaya

\section{BUILDING CULTURAL LITERACY THROUGH THE PATTINGALLOANG BOAT LIBRARY}

ABSTRACT: Building Indonesia to become a developed country is not an easy task and cannot be realized in a moment. Literacy is the ability to understand reading materials and the ability to write. The establishment of cultural literacy is the main prerequisite that can build a nation's human resources. The purpose of this paper is to analyze the challenges and opportunities of the Pattingalloang boat library in developing cultural literacy. The expected of this study is to scientifically contribute to the government and the public in harmonizing acceleration and description of building a cultural literacy. The study uses a descriptive qualitative method by presenting various relevant empirical facts and the data were obtained through relevant documents. The results concluded that firstly the Indonesian people have an interest in reading but the media to support it is still very limited. Secondly, the Pattingalloang Library Boat was presented due to two reasons namely literacy culture and cultural literacy. The last was the Pattingalloang library boat became a means of evidence of community contributions in developing literacy.

Keywords: Library boat; cultural literacy; literacy culture

\section{INTRODUCTION}

Literacy culture is a foundation for building human resources. In developed countries, literacy culture has become a part of people daily activities. That literacy can be adopted and implemented well in other countries like Indonesia. Indonesian society actually has the basic potential to enhance the Nation in many sectors because of local culture richness and religious life. For the local cultures itself, it is a valuable asset owned by each province from Sabang to Merauke, Miangas to Rote Island. 
Building literacy culture through local culture will at least lead to two things namely cultural literacy posture and cultural literacy. Meanwhile, religion is a medium that can neutralize and accommodate the tensions between two, local cultures and global currents. Taking into note, the challenges of local culture with the expansion of global currents, many surveys have studied.

The World Bank in June 2018 explained that there were 55\% of Indonesian people who had finished their education but could not apply knowledge in the community (Sharma, 2018). If it traced up this problem in-depth, then the answer will arrive at the limitations and availability of human resources

The Central Bereau of Statistics (Badan Pusat Statistik) in 2010 explained that Indonesia had had 1158 regional languages, but six years later or precisely October 2017, the Language Development Agency of the Ministry of Education and Culture (Badan Pengembangan Pembinaan Bahasa, Kementerian Pendidikan dan Kebudayaan) released that the remaining regional languages were 625 regional languages which are still used by people who inhabit $1,900,000 \mathrm{KM}$ of Indonesian territory. This data shows that in less than a decade the extinction of regional languages has exceeded $50 \%$. This situation was further strengthened by UNESCO, stating that every 15 days local languages in Indonesia experience extinction. Given the potential of language as a medium that can study a culture, it is necessary to design constructive steps such as creating collaborative media between elements of education and culture.

The increased numbers of this extinction from time to time is a warning for Indonesian people that the treasures of Indonesian cultures are in an alarming category. The results of BPS's qualitative analysis in collaboration with the Institute of Southeast Asian Studies (ISEAS) in 2013 revealed that the number of the legal owners of the local languages scattered in Indonesian territory amounted to 633 large tribes (Statistics, 2015). If a language is extinct then the information and culture of the community will automatically be disconnected and the next generation will lose the inheritance of science and customs that they have maintained so far. The impact of this may lead to the outside culture to enter and shifting local cultural identity.

Globalization raises danger and hope. The process of globalization which covers all aspects of modern life (economic, political and cultural) is reflected in social life. The way people understand the world, their own local world, and the whole world, is undergoing profound changes. New images of the world emerged. Some are at the level of reasoning based on common sense and some have been expressed in the form of special ideologies such as globalism or antiglobalism. (Sztompka, 2010)

Although the various facts are worrying, on the other hand, there are also interesting facts that Indonesia has attracted foreign investors to increase the amount of investment by the time. This is certainly an opportunity as well as a challenge for Indonesian people. The opportunity is that that natural resource management can be optimized to develop the nation and absorb Indonesia's human resources in various jobs. This will raise the standard of living, keep pace with population growth and can reduce unemployment and overcome poverty which is a global problem in developing countries.

While the challenge is that the Indonesian people must first have competitive human resource qualifications. Indicators of human resources by default have at least an educational background, skills in accordance with the needs of the labor market and can communicate using a foreign language. Indonesian people must have a commitment to the preservation of their cultures. Referring to the Presidential Regulation of the Republic of Indonesia (Peraturan Presiden Republik Indonesia) Number 2 of 2015 concerning the 2015-2019 Medium-Term Development Plan (RPJMN), it includes the main challenges of development by bringing together two streams of power which are market commodities and the nation's cultures.

Consequently, the Nation is in the midst of a battle between two main streams. On one hand, Indonesian people are confronted with cultural streams driven by market forces that place humans as mere commodities. On the other hand, there is a flow of culture that emphasizes the strengthening of primordial identity in the midst of the rapid flow of globalization. The 
accumulation of failure to manage the effects of these two main streams leads to a threat to the development of national character. (Indonesia, 2014)

Various concrete steps must be taken immediately as an effort to build human resources and provide motivation to the community for strengthening the role of the Indonesian people in the international arena without leaving their identity. Indonesia has the potential for this, besides being supported by abundant of natural resources, diverse local customs, Indonesian people are known as religious society.

The strategic way in building Indonesian human resources is through infrastructure development and pay more attention to education. Education is not only informal institutions but non-formal and informal support for each other. We may learn from Japan, a country that was previously destroyed during World War II, but now is becoming a country with technological giant in the world.

Indonesian society is known as a plural society. This can be seen in the social reality and the Nation motto "Bhineka Tunggal Ika" (Unity in Diversity). The diversity of Indonesian people is marked by various differences both horizontally and vertically. Horizontal differences include social entities based on ethnicity, language, customs, and religion. Whereas the vertical differences concerning the differences between the upper and lower layers in our society today are very sharp, both in the social, economic, political and cultural fields (Al-Munawar, 2006)

Globalization is an era that must be faced with all its consequences. If the government makes regulations in the field of education with curriculum development, then each element of society is engaged to develop human resources with their potential. The government's boat library is a strategic step in building community interest in reading.

\section{LITERATURE REVIEW}

Literacy is no longer limited to the ability to read and write but is far broader than that. The meaning of literacy has been far more developed into the ability to obtain and process information into new knowledge. Knowledge literacy is a form of ability possessed by a person after obtaining data or information and processing it into new knowledge expressed both verbally and in writing. In other words, new knowledge is an individual perspective on a series of inputs that he/she receives in the form of both text and non-text (T, 2015).

The application of information technology in libraries has now become a necessity, and has become an effort to improve various library services that can be accessed maximally by all library users themselves. Through the application of information technology all activities in the library can run faster, more accurately and efficiently (Maryam, 2010).

Literacy education is very important to be raised considering that a developed nation can see how its people have implemented literacy culture in their daily lives. Literacy in this case includes the ability of humans to maximize their full potential. If this happens globally, not only development but can lead a country to become a developed country.

Developing literacy education through massive investment in human capital is the first step in enhancing sustainability literacy. There are two mindsets on the attainment of the 17-point sustainable development goals. First, is on decreasing human vulnerability with focus on nine goals. Second, is on increasing sustainability with focus on eight goals. Literacy education on the environment, production, preventative actions, personal income generation and improved human capacity, social justice through the sustenance of democratic institutional structure among others, will enhance sustainable development in any knowledge economy. It is recommended that; sustainability of literacy education should be part of public policy instruments to promote sustainable development. Second, for literacy education to drive knowledge economy it must be futures, values, systems, and strategic thinking respectively to ensure sustainable development (E. Oghenekohwo \& A. Frank-Oputu, 2017).

\section{RESEARCH METHODOLGY}

The qualitative method was used in this study in which the data were gathered through reviewing relevant documents. The approach used is a methodological approach that refers to phenomenology. The data collection technique was carried out by performing data searching 
through books, journals or online sources. This research has also elaborated literacy culture and cultural literacy that has been carried out by literacy activists in the village of Pambusuang, Polewali Mandar Regency by presenting the Pattingalloang library boat.

\section{FINDINGS AND DISCUSSION}

\section{a. Cultural Literacy}

The flow of science and information preservation can at least be known and analyzed by two media sources; literacy culture (read-write) and orality (oral culture). Archaeologists know that caves and river banks were ancient human dwellings because there were paintings on cave walls and found piles of thousands of years old food scraps (Kjokkenmoddinger) on river banks and shores. The gravity theory by Isaac Newton (1642-1726 AD) was the result of his reading from the apple incident (apple incident). The title Amir al-mu'minin fil Hadith, the most comprehensive Hadith writer, Abu Abdullah Muhammad bin Ismail bin Ibrahim bin Mughirah bin Bardizbah al-Bukhari (810-870 AD) better known as Imam Bukhari has written a collection of Sahih Hadith (Jami as-Șahih) that is inseparable from his like to do rihlah (discover) looking for Hadith both obtained through oral sources and the results of his analysis of the traditions that he has written and classification.

Oscar Cameron Gruner, the author of The Canon of Medicine of Avicenna published in 1929 in London, was inspired by his reading of the phenomenal work of Muslim scientist Ibn Sina (980-1037 AD), al-Qānūn fi al-Țibb. It is important to know before Oscar Cameron Gruner wrote The Canon of Medicine of Avicenna, al-Qānūn fĩ al-Tibb's book had earlier become the main reference in the discussion of medical science at various leading universities in Europe. Even the various medical terms that exist in the book, since the mid-eighteenth century until now is still used (Haddad, 2009). If culture is born from a community tradition handed down from generation to generation, then an author sees a great opportunity for cultural literacy as information media and preservation of science, and can also be an effort to preserve culture for the next generations. Culture is a way of life that developed from society and is passed down from generation to generation. Culture is the essence of national life. Getting to know the nation's culture means knowing aspirations itself in all aspects of life (Sinaulan, 2018).

Tutik Hasnah, in the Islamic Golden Perspective: Benang Merah Sejarah Islam (Islamic Golden Perspective: The Thread of Islamic History) equates cultural with the word 'intelligent': "Culture is derived from Sanskrit which means commensurate with words of understanding in Arabic. So what is meant by culture here is to be a human who uses his mind. In the language of the Koran is la'allakum ta'qilun (تعلكم تعقلون). If we pay attention to the verse that ends with the editorial ل, we can interpret "so that humans use their minds" or that humans become cultured" (Hasanah, 2012).

When culture is used as a media to build literacy culture, the impact that Indonesia will eradicate illiterate and a means of preserving Indonesian culture. While the long-term impact is that Indonesian will have superior resources that might contribute to the world.

\section{b. The Pattinggalloang Boat Library}

The Pattingalloang library boat is a boat library owned by Armada Pustaka Mandar (the Mandar Library Fleet), a literacy community located in Pambusuang Village, Polewali Mandar Regency. The choice of the boat as a medium in building literacy culture due to the Mandarese fishermen can still make and even operate the traditional boat, known as Sandeq. In addition, besides Sandeq there are still many other types of boats used by the Mandarese fishermen. Among the types of boats that are familiar used by Mandarese fishermen, there are Baqgo boat, known as Patorani boat in Makassar, which are the most suitable boat models made as library boat. German maritime tradition researcher Horst H. Liebner explained:

"... the name of the Baqgoq boat from the Mandar and Barru regions refers to the type of boat hull if it uses a sloop ('nade') type screen - if it is equipped with a type of lateen screen ('lete'), the sailors will name it Baqgoq or lete. Boats that use schooner-ketch ('pinisiq') sails are called Pinisiq, so that the hulls of the boats are shaped like a back, palari, or lambo; Patorani type 
boats (flying fish finders [torani]" from Galesong, South Sulawesi, consist of two large pajala hulls or small backs and use rectangular rig tilter ('tanjaq ') sails" (Horst, 2004).

Although only few Mandarese fishermen are still capable in making Baqgo boats, but until now these boats are very difficult to find. This is due to many fishermen switching from using traditional boats to boats that use engines, known as Katinting. Besides economic factors, Katinting no needs to wait for the wind to move the boat, the use of engines can also speed up the mobilization of fishermen's catches. Muslimin explained about the posture and the number of Baqgo boats around the Mandar Bay.

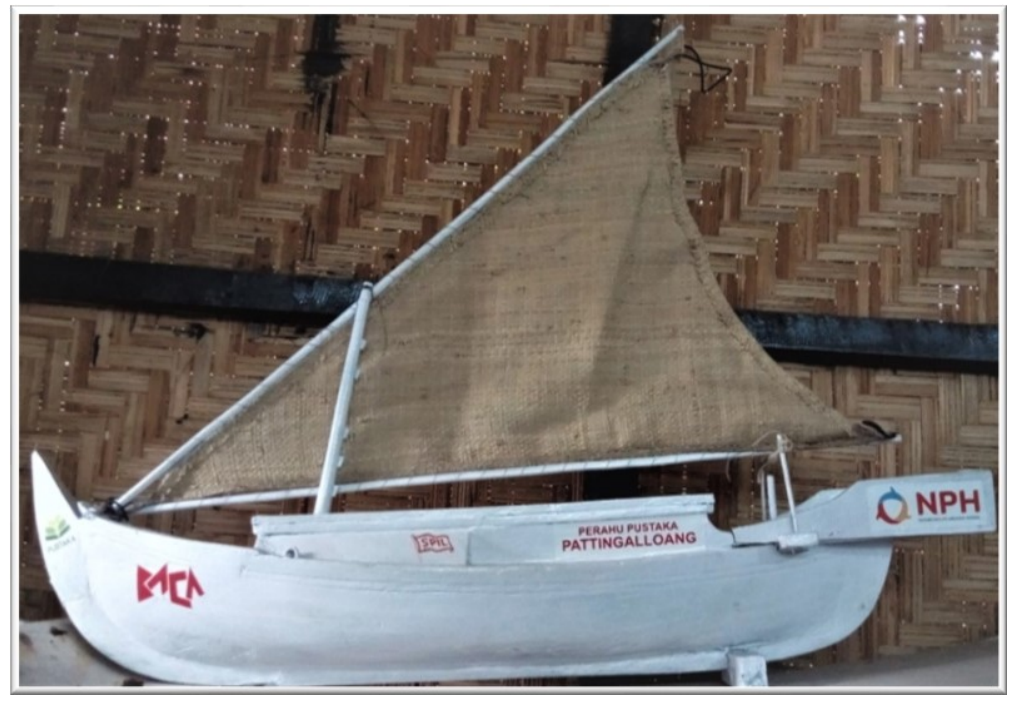

Figure 1. Miniature of Baqgo

"Baqgo boats have large hulls and can hold and carry large numbers of books, and Baqgo boats are also used to preserve culture. The Baqgo boat uses engine power and there is also wind power and if you want to get there quickly the sails and engine are activated together. About the number of Baqgo boats that have been categorized as extinct as far as my vision. The number of Baqgo boats is remaining only one, yes, it is the library boat belonging to the Mandar Library" (Muslimin, 2019).

Some important points that make the Baqgo chosen as a library boat, as follows:

1. It has a large posture so that it can accommodate sailing equipment, has room chambers for boat crews, and is very adequate for carrying library materials;

2. Baqgo has hulls and stern which can be docked in shallow waters;

3. If you pay attention to the geographical conditions of the area which will be the orientation of literacy visits more dominant on the coast and rivers, it is very suitable with the selection of Baqgo as a library boat;

4. Making Baqgo as a library boat is the same as preserving some parts of Indonesian maritime traditions. Considering that in the early days the Baqgo boat was a boat that had been used by Mandarese fishermen or Sulawesi fishermen to search for sea cucumbers not only in the Sulawesi sea even to Australia. Through this moment at least the current generation can still see the boat and enjoy the cruise with Baqgo, and

5. Human resources who capable to produce and operate the boat still exist.

\section{c. The Pattingalloang Boat Library Model Builds Cultural Literacy Through Literacy Culture}

The given name of the Pattingalloang library boat was inspired by two things. First, the name of the boat was taken from the theme of the 2015 Makassar International Write Festival (MIWF), which raised the biography of the scientist Gowa-Tallo, Karaeng Pattingalloang, "Universe and Knowledge: Karaeng Pattingalloang". This activity was held sometime after the library boat entered the finishing stage. 


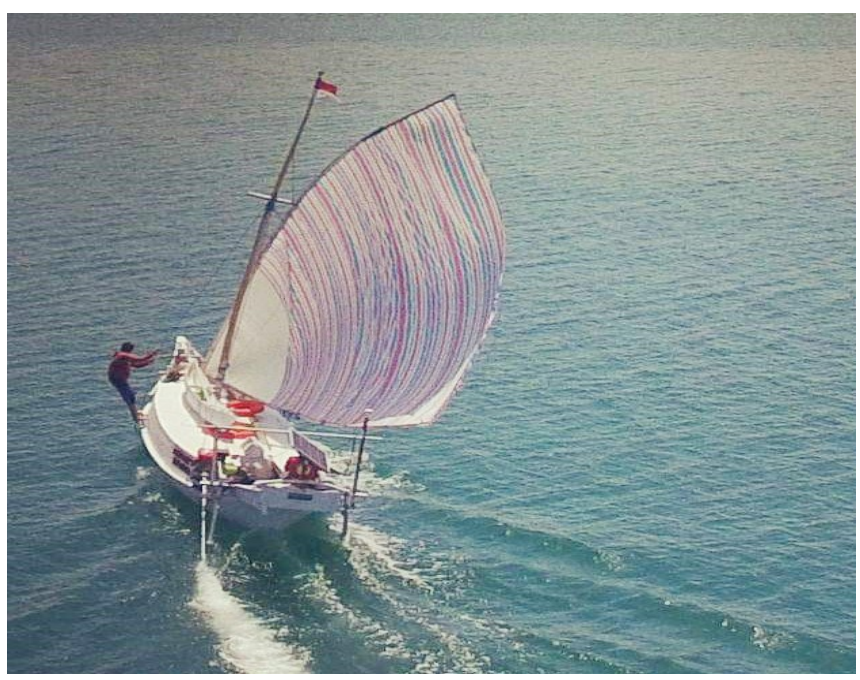

Figure 2. The Pattingalloang library boat sailing

A book, Sultan Muhammad Abdullah The Great Pattingalloang Visinoer Scholar of the PreColonial Period 1600-1654, informs that Karaeng Pattingalloang was the son of Karaeng Matoaya Tu Menanga Ri Agamana or Sultan Abdullah Awwalul Islam, aristocrats of the GowaTallo kingdom who ruled in the XVI Century and became a mangkubumi of the royal kingdom. Gowa-Tallo was the first to embrace Islam. Since a young age, Pattingalloang is famous as a child who loves science, always carrying books and mastering a variety of languages in the world.

"Pattingalloang's intelligence in understanding and fluent in using a variety of foreign languages: Portuguese, Dutch, English, French, Arabic, Malay, and Javanese, as well as local languages at the time, such as the Bugis and Mandar languages, further established himself as a multilingual character that gave him space for explore various fields of science and technology" (Awliya, 2015).

Pattingalloang confirmed his status as a world-class scientist with ownership of certain goods which were very rarely owned by the public at that time. Prestigious findings in the field of medieval science such as maps, globes, and telescopes, all of which Pattingalloang has. Pattingalloang also succeeded in combining various maps of the world in one unity. Maps from various parts of the world, partly derived from maps made by Bugisnese-Makassarese people, are the first maps of the earth that are considered the most complete (Awliya, 2015). Hence, based on Pattingalloang's dedication to science is deserved using his name to enshrine as its library boat.

Pattingalloang Library spent in building a literacy culture that had been taken place before the boat was physically completed. In terms of time, ideally, Baqgo can spend minimum a year to build, from searching materials, drying wood to the completion of the boat. But taking advantage of the Makassar International Write Festival (MIWF) moment held in June 2015, the establishment of the boat was approximately completed only 2 months from April to the first week of June 2015.

Secondly, the author analyzes the taking of the name of the Gowa-Tallo aristocrat, Pattingalloang, the name of the library boat, is an effort to build cultural literacy and a means to tighten back, that between Mandar and Makassar has a moral-historical knot that has been woven since the Sixteenth Century. The first king (Maraqdia) in the Kingdom of Balanipa (Mandar) was I Manyambungi Todilaling. I Manyambungi Todilaling is the son of King Napo (Tomakaka Napo) who once served as a member of the military (juak) and was given the mandate as a warlord in the Kingdom of Gowa.

"I Manyambungi then lived and grew up in the Palace of the King of Gowa. There he studied the science of war. Because of his skills, he was appointed as the warlord of the Kingdom of Gowa. He had led war expeditions to Pariaman and Tambora. He became the favorite of King Gowa and 
was married to a Syrian karaeng (king) daughter, a close relative of King Gowa" (Saprillah \& Idham, 2011).

I Rerasi is the daughter of the first King of Balanipa, I Manyambungi and mother of the $9^{\text {th }}$ King of Gowa, Daeng Matanre Karaeng Tomapa'risi Kallonna (1512-1546). In addition to I Manyambungi Todilaling, there is also Daeng Rioso the King of Arajang XII Balanipa. Before being asked to become the King of Balanipa, Daeng Rioso had been assigned as the commander of the Balanipa Royal War. During his time as Balanipa Royal Warlord, Daeng Rioso was also an important part of Makassar's highly respected sea commander in partnership with I Pakkebu Karaeng Jarre Karaeng Bontomarannu Karaeng Galesong to take part in pounding the VOC and its Allies out of the Gowa Kingdom.

Naming boat library through this information has a pretty strong indication that between the Kingdom of Makassar and the Kingdom of Balanipa, which is in Mandar region has been woven through family and political channels. Therefore, a step that would be appropriate for Pattingallolang as a nobleman and scholar of the Kingdom of Gowa became the name of a library boat in the hope that for the present and next generation could gain lessons from Pattingalloang's dedication in developing knowledge and reaffirming the moral ties between Makassar and Mandar. Hence, in its journey, the Pattingalloang Library Boat has reconstructed cultural literacy and literacy culture at the same time.

Its toughness in developing cultural literacy from the beginning until now is no doubt. On June $3^{\text {rd }}, 2015$, after the first voyage from the Mandar Bay to several meters offshore in front of the Fort Rotterdam in Makassar, the author visited and met Muhammad Ridwan Alimuddin and even had a chance to talk with Pua Marni (library boat designer). Pua Marni, besides making the Pattingalloang Library Boat, he has also the ability to sail and sail the boat from Polewali Mandar to Makassar as well as his return. The Pattingalloang Library Boat sailed in Makassar Strait, Bone Bay, Flores Sea in commemoration of International Book Day on April 23 $3^{\text {rd }}$.

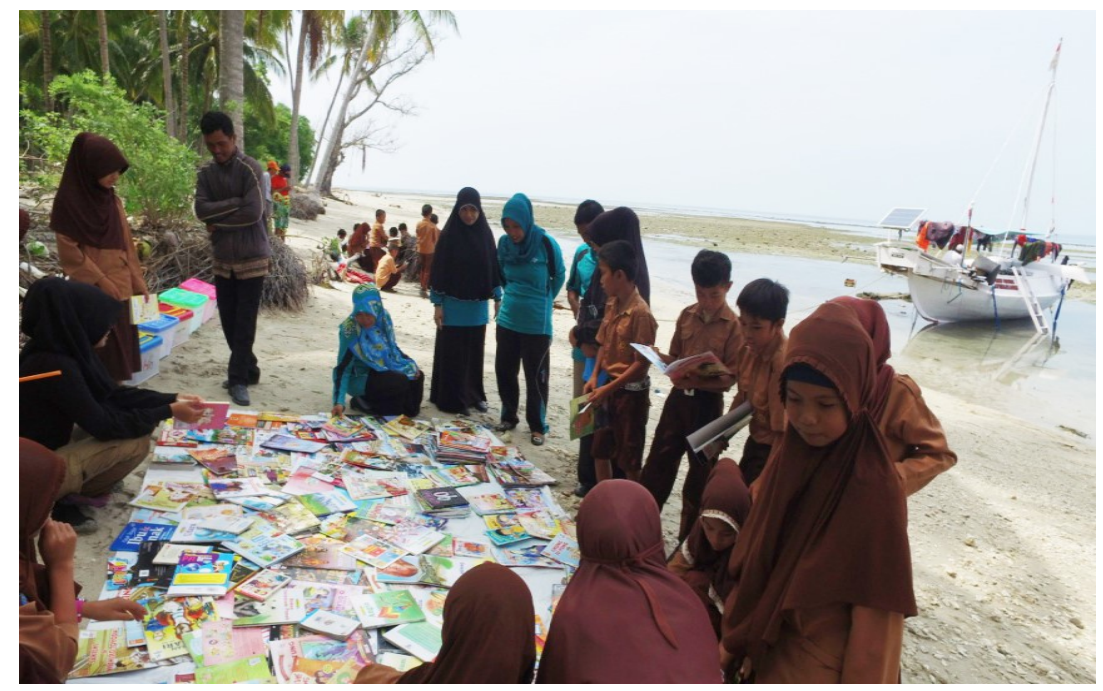

Figure 3. Building literacy

"The first cruise has taken action starting from the village of Polewali Mandar to dock in the Makassar Strait, near Fort Rotterdam. At that time the boat was still unpainted. Besides to building a literacy culture in the Polewali Mandar districts, the Pattingalloang Library Boat has ever sailed in Makassar Sea to Sagori Island (Southeast Sulawesi)" (Alimuddin, 2019).

For long-distance cruise,s, the library boat at least carried out 5 to 6 crew members. One person as the captain, two persons as the crew of the ship (sawi) while the rests are volunteers. There is something interesting to note in involving volunteers because there are no specific criteria for being volunteers. Capital trust and readiness are the main concerned. The most important is to have an ideology, quickly adapt and of course, have the same passion which is building cultural literacy. 


\section{CONCLUSION}

Cultural literacy is a basic and main thing in developed countries. If a country, like Indonesia, wants to be a developed country, at least the country has at least to adapt to the good habits that occur in developed countries. The Pattingalloang Library Boat has built literacy by combining two elements; education and preservation of Indonesian culture. Every sail, cultural literacy and literacy culture has occurred at the same time. Pattingalloang library boat chosen Baqgo as a prestigious way due to this type of traditional boat towards extinction.

\section{REFERENCES}

Al-Munawar, SA (2006). Jurisprudence Life Interfaith Cultural-based Community Organizing, Future Seminar Series Nations and Religious Radicalism. Bandung: Mount Djadti Press.

Alimuddin, MR (2019). The master and leader of the Fleet Library Mandar. Pambusuang.

Awliya, F. (2015). Sultan Muhammad Abdullah The Great Pattingalloang Scholars Visinoer precolonial 1600-1654. Jakarta: The Gemma Nine National Institute for Empoerment.

Badan Pusat Statistik (2015). Data mengulik tribe in Indonesia.

Haddad, K. (2009). 12 People of the World Changers. Jakarta: Gema Insani.

Hasanah, T. (2012). Islamic Golden prespective Yarn history by Islam. Solo: Ink Medina.

Horst, HL (2004). Maritime tradition in South Sulawesi: Historical Overview of Shipping and Shipping in Continuity and Change in the History of South Sulawesi. Yogyakarta: Waves.

Joseph .T, M. (2015). Influence of Learning Strategies with WebQuest And E kasi Yourself Against Increased Knowledge Literacy. JTP - Journal of Educational Technology, 17 (1), 15-25.

Minister of National Development Plannding (2014). Indonesian Presidential Regulation No. 2 of 2015 on the Medium Term Development Plan (RPJMN) 2015-20019 Book I.

Maryam, S. (2010). The ability of HR Information Technology Library in UIN Jakarta. ALMaktabah, 10 (1).

Muslims. (2019). The author's thesis boat Pattingalloang Library. Gowa.

Oghenekohwo, J. E, and Frank-Oputu, E. A. (2017). Literacy Education and Sustainable Development in Developing Societies. International Journal of Education and Literacy Studies, 5 (2), 126. https://doi.org/10.7575/aiac.ijels.v.5n.2p.126

Saprillah, and Idham. (2011). Identity Malaqbiq People Mandar (I). Solo: Zada Hanifa.

Sharma, D. etc. (2018). Learning more, growing faster. In Indonesia Economic Quarterly. Retrieved from www.worldbank.org/id.

Sinaulan, J. (2018). Acculturation Hindu Cultural Identity in the Era of Multiculturalism. Ideas: Journal of Educational, Social and Cultural Rights, 4 (2), 215-224.

Sztompka, P. (2010). The Sociology of Social Change trans. Alamandan, Sociology of Social Change (V). Jakarta: Prenada. 